\title{
Paleogene microfossils from the submarine debris flows in the Skole basin (Polish and Ukraine Outer Carpathians)
}

\author{
Andrzej Szydło, Małgorzata Garecka, Leszek Jankowski, Tomasz Malata \\ Polish Geological Institute - National Research Institute (PGI-NRI), Carpathian Branch; \\ ul.Skrzatów 1,31-560 Krakow; e-mail: andrzej.szydlo@pgi.gov.pl, malgorzata.garecka@pgi.gov.pl, \\ leszek.jankowski@pgi.gov.pl,tomasz.malata@pgi.gov.pl
}

(C) 2014 Authors. This is an open access publication, which can be used, distributed and reproduced in any medium according to the Creative Commons CC-BY 4.0 License requiring that the original work has been properly cited.

\begin{abstract}
Biostratigraphic analysis of fossils material has allowed the documentation of sediment gravity flows in the Skole basin during the Paleocene and Eocene times, and also in the Eocene-Oligocene transition. This most external basin of the NE Outer Carpathians was a marginal sea especially sensitive to geotectonic instability and relative sea-level change, favoring the development of down slope movements at these times. The dominance of calcareous forms in foraminifera, and a large share of redeposited species among the nanno- and microfossils indicate a close relationship of sediments containing them with the shelf environment and documents not too long transport. Additionally the recycled forms are often well preserved, indicating that the rock contained in flows were only plasticized and hydrated while the material itself was not a subject of significant mechanical processing in contrast to that one, which directly documented down slope moving. The latter forms are bad preserved and their fossil remains are usually corroded, partially dissolved and broken during this process. In addition, the planktonic forms including foraminifera, calcareous dinocysts and nannoplankton allow documenting the time of the final deposition of the sediment transported on slope.
\end{abstract}

Keywords: foraminifera, calcareous nannoplankton, biostratigraphy, palaeoenvironment, gravity flows, Skole unit, Outer Carpathians

\section{INTRODUCTION}

The Outer Carpathians successions in Poland and Ukraine are seen primarily as a wide range of deep water sediments, which were deposited by turbidity currents of different densities. They represent mainly siliciclastic deposits of turbidity facies, called flysch (Książkiewicz 1958, Kruglov 1989, Ślączka et al. 2006). In fact they represent the products of resedimentation processes that constantly took place in this part of the Outer Carpathians basin during its geotectonic evolution. These processes were initiated by the Late Jurassic-Early Cretaceous rifting on the southern margins of the North European Plate and finally completed by the Early Miocene geodynamic transformation (Ślączka et al. 1999, Golonka et al. 2000, Oszczypko 2006). At the time, deposits accumulated on the continental margins and uplifted areas moved regularly down slopes the influence of gravity and other body forces, which acts on the interior particles in a relatively short time (Książkiewicz 1958, Barber 2010). In modern oceans, these submarine mass movements are usually being activated by shock events (e.g. earthquakes, volcanic 
eruptions, storm waves) and rapid sediment deposition. This phenomena may also appear during cyclic sedimentation on slopes, where periodic instability is the consequence of too much sediment load (Lee et al. 2007). Depending on the degree of textural-structural deformation and water saturation, the moving deposits take various forms, which are described as slumps, sediment slides, and flow deposits including also turbidities (Middleton \& Hampton 1973, Prior 1984, Postma 1986, Norem et al. 1990, Mulder \& Cochonat 1996, Lee et al. 2007). Turbidities have the greatest thickness and stratigraphic range and often mask other products of sediment gravity flows, which are not so frequent and occur locally in the sedimentary basins. These deposits include heterogeneous material varying in size and sorting. This materialis cemented by a matrix of fine sediment sometimes predominantly muddy. Depending on the proportions of these components, these deposits are formed by mud or debris flows (Postma 1986, Dasgupta 2003, Lee et al. 2007).

The presented studies concentrate on the foraminifers and calcareous nannoplankton from the deposits reworked by a rapid downslope flow of poorly-sorted debris mixed with water (debris flows sensu Johnson \& Rodine 1984). Deposits of this type occur in the Paleogene series of the Outer Carpathians in Poland and Ukraine (Dżułyński et al. 1959, Dżułyński et al. 1979, Ślączka \& Kaminski 1989, Kruglov 1989, Rajchel 1990) (Fig. 1). These rocks belonging to the Skole unit differs from the surrounding turbidities by their textural-structural and genetic features, and also by the microfossils. In contrast to turbidities, deposits formed by debris flows include a mixed foraminiferal assemblages dominated by planktonic and calcareous benthonic forms. Agglutinated forms belong to accessory elements of these assemblages (e.g. Geroch et al. 1967, Szczechura \& Pożaryska 1974, Olszewska 1985, Olszewska \& Malata 2006, Szydło 2011). Their diversity, number of specimens, ecological preferences and preservation in relation to characteristic features of phytoplankton (coccoliths and calcdinocysts) from the studied deposits has been examined for biostratigraphical and environmental analysis.
Moreover, taphonomic features of studied fossils and their fossilizing potential have been discussed. Finally, micropaleontological data has been discussed in geologic and sedimentologic context. The age of studied deposits was based on calcareous macrofauna: bivalves and snails (Bukowy \& Geroch 1957, Krach 1969, Kotlarczyk 1979, 1988, Piotrowski \& Piotrowska 2004) and also foraminifers (Szczechura \& Pożaryska 1974, Morgiel \& Szymakowska 1978).

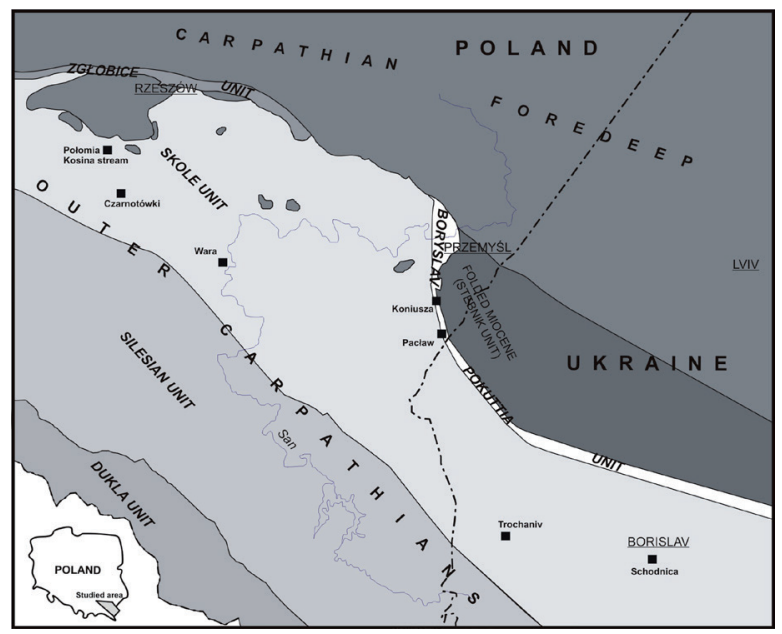

Fig. 1. Geological sketch of Outer Carpathians in borderland of Poland and Ukraine (Jankowski et al. eds 2004, Kotarba \& Kottun 2006, compiled)

\section{GEOLOGICAL SETTING}

The Skole basin, located in the northeastern part of the Outer Carpathians, which extends today between Poland and Ukraine. In this area, described deposits outcrop only in some localities. They are often masked by turbidities of greater thickness and extent (Dżułyński \& Kotlarczyk 1965, Dżułyński et al. 1979, Szymakowska 1976, Kotlarczyk 1978, 1979, Olszewska 1985, Rajchel 1990). They are classified as the laterally discontinuous and stratigraphically designated units, which form lenticular bodies of rocks different in size, changing lithology, and positions within series of turbidities (Fig. 2). They include the Paleocene Babica clays, the Lower-Middle Eocene Czudec clays, and the Upper Eocene-Lower Oligocene Popiele beds. Other mudstones, which irregularly occur within or on the margins of different turbidite 


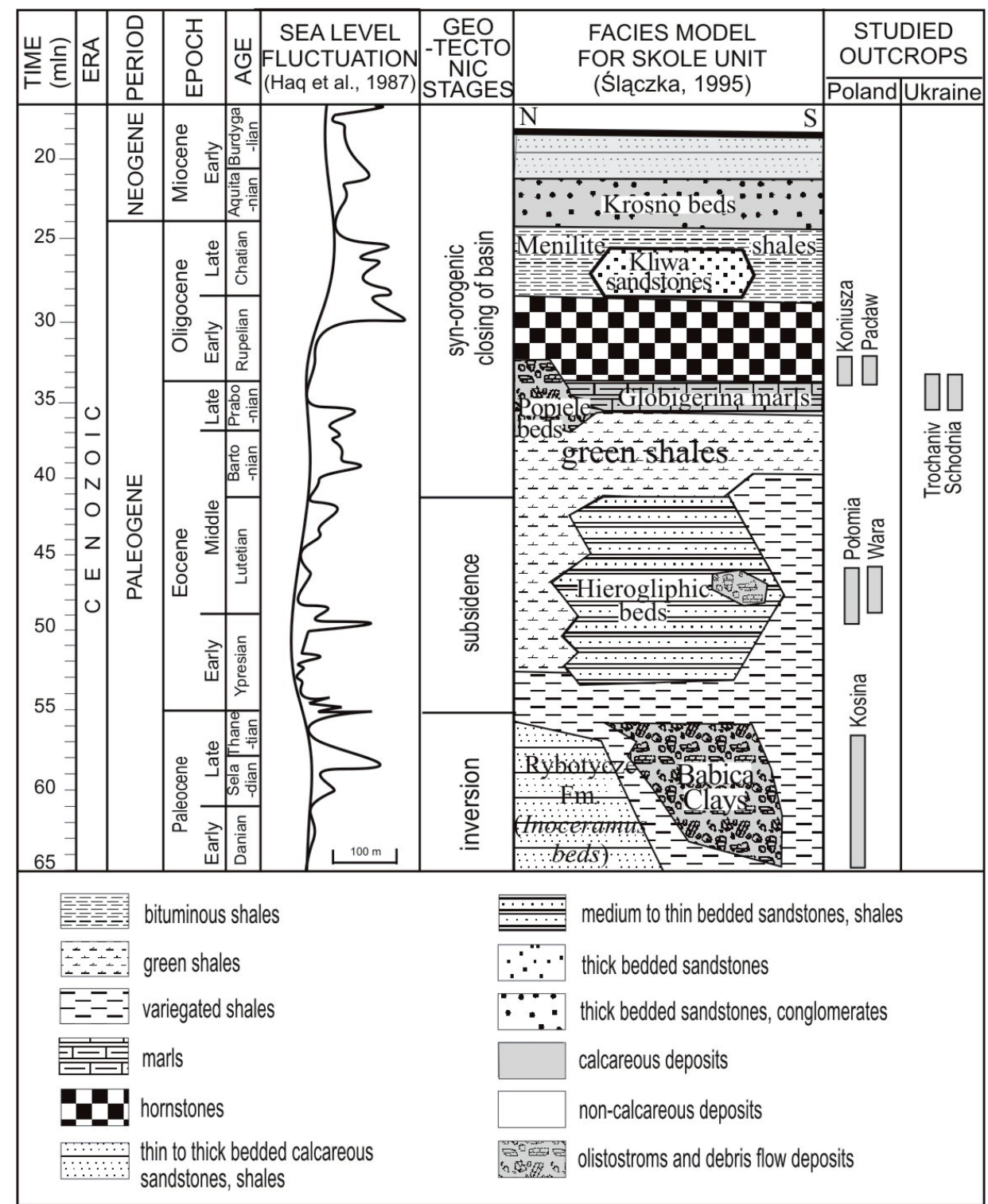

Fig. 2. Simplified facies model for the Paleogene-Neogene deposits of the Skole unit in relation with the geochronologic and stratigraphic scales and sea-level fluctuations, and also main geotectonic evolution of the Outer Carpathians (Gradstein \& Ogg 2004, Oszczypko 2006, Ślaczka et al. 2006)

series e.g. the Senonian-Paleocene Inoceramus beds (partially corresponds to the Variegated Shales Formation proposed by Rajchel in 1990), the Eocene Hieroglyphic beds (=Hieroglyphic Formation sensu Rajchel 1990), the Oligocene menilite shales (=Menilite Formation of Kotlarczyk \& Leśniak 1990), and the lower part of the Krosno beds (partially corresponds to the Krosno Formation proposed by Wójcik et al. (1995) and Malata (1996). In the Paleogene, the Outer Carpathian Basin was divided into several deposition areas, which were separated by elevated zones including the Silesian ridge and the Subsilesian zone. The first separated the two innermost sub-basins (Magura and Silesian sub-basins) while the other one become a barrier between the outer Skole sub-basin, and the Silesian and Dukla sub-basins.

\section{SEDIMENTOLOGICAL REMARKS}

The origin and mechanisms of sediment gravity flows have been described and interpreted based on the laboratory experiments and observations 
of submarine mass movement in modern oceans (Middleton \& Hampton 1973, Postma 1986, Dasgupta 2003, Felix \& Peakall 2006, Lee et al. 2007, Parsons et al. 2007). These processes often overlap each other and usually pass into each other on slopes. Consequently, the submarine landslides initiated in the upper part of the slope transform successively into cohesive or turbidity currents at the basin's rise. If sediments slides disintegrated and liquefied, gravity flows formed on a slope. Then, if the process is continued, the debris flow have become increasingly reworked, dispersed in the water, and finally evolved into high and low concentration turbidity currents (Hampton 1972, Parsons et al. 2007, Felix et al. 2009). Processes of this type took place in basins of the Alpine folds system (Ślączka et al. 2006, Picha et al. 2006, Felix et al. 2009).

One of them is the Skole basin. These settings, which were mainly characteristic for the Late Cretaceous, changed at the Cretaceous/Paleogene boundary. The first symptoms of these changes were documented in the Skole sub-basin during the Maastrichtian time. In that time Makówka breccias formed. These deposits occur at the upper part of the Inoceramus beds (=Ropianka Formation, Kotlarczyk 1978) and include poorly sorted clasts of small size embedded in a gray and gray-blue marly mass usually few meters thick (Kotlarczyk 1978 1988, Rajchel 1990). At the end of the Paleocene, the subsidence linked to the rise in a sea level was intensified (Poprawa et al. 2002). This event may be correlated with the deposition of the Babica clays. They are recognized as the isolated, few to several meters thick rock bodies. These deposits, occurring at the top of the Inoceramus beds of the Skole unit, are dominated by dark gray clays, which contain siliciclastic and carbonate clasts, whose size reaches tens of centimeters. Thin beds with crushed shells of mollusk, sandstones, and conglomerates also occur in these deposits (Bukowy \& Geroch 1957, Kotlarczyk 1979). In the above lying Eocene Hieroglyphic beds, the Czudec clays appear as local rock bodies, which contain brown mudstones with claystones intercalations including also varied sandstones and conglomerates. The discussed, several meters thick deposits occur irregularly within turbidity series
(Rajchel 1990). The geotectonic transformation and changes in the sea-level caused the appearance of these deposits. The Outer Carpathians included residual oceanic sub-basins, connected with the global ocean (Golonka et al. 2000). They were transformed into mountain basins during the late Eocene tome. This transformation of the Outer Carpathian Basin led to the termination of deep-water sedimentation of turbidites and variegated shales. These deposits were replaced by pelagic marls (Globigerina marls) in the latest Eocene, and then in the Early Oligocene by bituminous shales (Menilite shales), which were formed under anaerobic conditions or in environments with a very large short age of oxygen under reducing conditions (Oszczypko 2006). These changes in the depositional system were correlated with the appearance of the Upper Eocene-Lower Oligocene Popiele beds (Krach \& Liszka 1961), which are most completely developed in the Ukrainian part of the Outer Carpathians, where their thickness exceeds $100 \mathrm{~m}$ (Rajchel 1990). These lithologically diverse deposits are represented mainly by brownish-gray or greenish, very sandy mudstones, horizontally laminated or unstructured. They pass into the sediment of olistostrome type by a gradual increase of detached blocks in their content. Among the characteristic components of olistostrome, detached blocks derived from the Hieroglyphic beds (green shales, sandstones and marls), Menilite series (gray, brown and black shales, siderites, and coarse-grained glauconitic sandstones similar to the Kliwa sandstones), and fragments of coal dominate. Individual blocks or landslide lobes reach several meters in diameter (Rajchel 1990). After anoxic episodes in the Early Oligocene, correlated with a drastic sea level fall in the Skole basin, the sedimentation of the sandstones series of large thickness took place (socalled Krosno beds). They were deposited under conditions of increasing subsidence (Haq et al. 1988, Kotlarczyk \& Uchman 2012). This process occurred in the foreland of the Magura Nappe, which included the Subsilesian, the Silesian, and the Skole sub-basins during the Oligocene times. The folded Magura series gradually moved northward, closing sub-basins. During the Paleogene-Neogene transition, sedimentation 
of the Krosno beds ended as a result of complete closure of the sub-basins. During these processes, mudstones appeared in the Skole basin (Oszczypko 1998). These sediments contain calcareous microfossils and exotics, which were found within the Menilite-Krosno series (Kotlarczyk 1979, Olszewska 1985, Kotlarczyk \& Leśniak 1990).
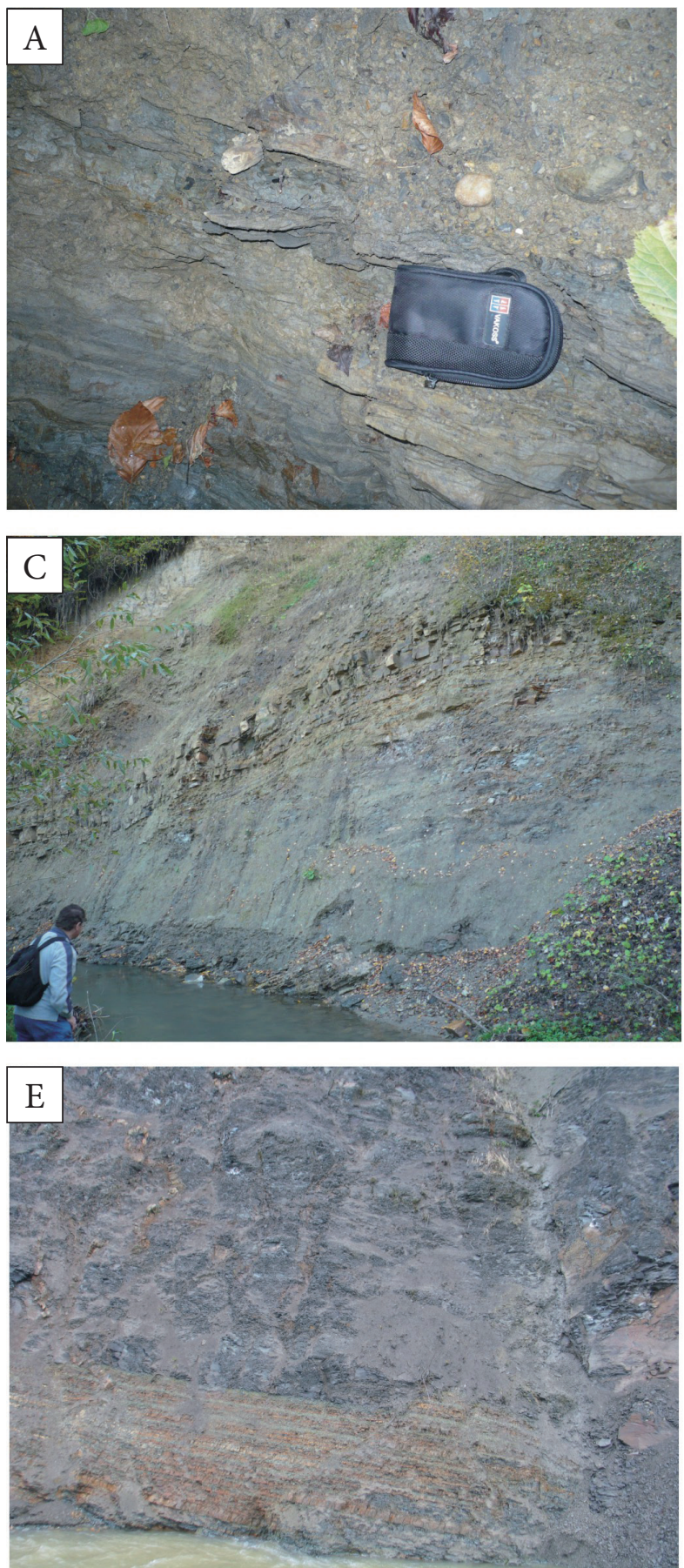

Fig. 3. Outcrops of the Babica clays in Kosina stream: A) clays with olistoliths; B) black mudstones with crushed shells of mollusk; the Czudec clays in Wara: C) rhythmic series; D) lithological boundary with the Hieroglyphic beds; the Popiele beds: E) rhythmic mudstones series (Schodnica); F) mudstones series with olistoliths and removed fragments of beds (Trochaniv)

\section{STUDIED AREA}

The studied samples (Fig. 3) were collected during the field works (in cooperation with Leszek Jankowski and Tomasz Malata, Carpathian Branch of PGI-NGI) from deposits formed by debris flows, which were documented in the turbidity series.
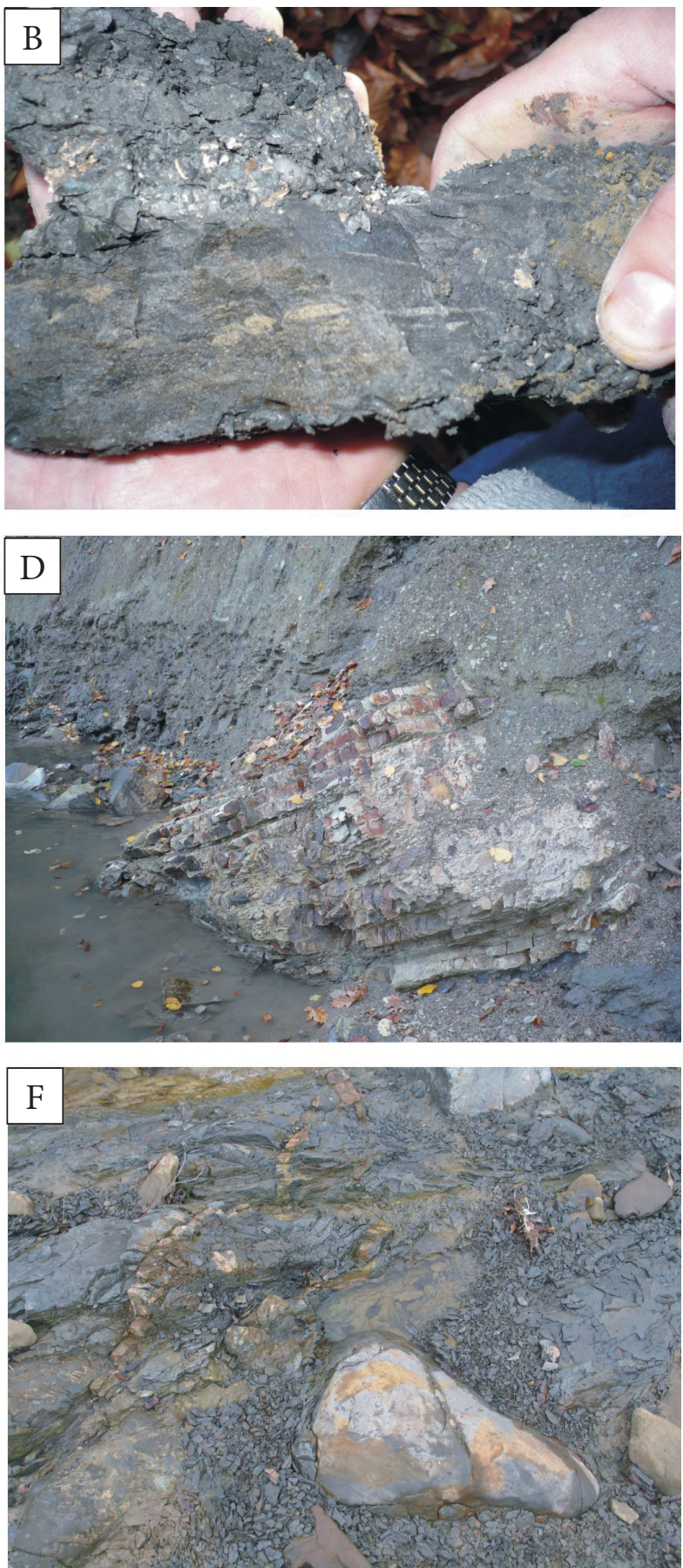
These series which outcrop in the NE part of the Outer Carpathians extending between Poland and Ukraine. The presented studies carried out on deposits belonging to the Skole unit, which expose in the Dynów Foothills as the Babica clays: Kosina stream in the vicinity of Połomia (Fig. 3A, B) and Czarnotówki localities in Poland, the Przemyśl Foothills as the so-called Czudec clays: Wara (Fig. 3C, D), Połomia and Czarnotówki localities in Poland, and also in the front of the Eastern Beskid as the Popiele beds in Poland (Koniusza and Pacław localities) and Ukraine (Trochaniv and Schodnica localities) (Fig. 3E, F).

\section{METHODS}

In this study, mainly foraminifera and calcareous nannoplankton, as well as sometimes calcdinocysts and ostracods were used for micropaleontological analyzes. The foraminifers were separated from the rock samples (about $1 \mathrm{~kg}$ ), by successive boiling and freezing and then washed in a sieve $(125 \mu \mathrm{m})$. Finally, the $63 \mu \mathrm{m}$ fraction was used for observation. Calcareous nannoplankton came from scraped fine dust of the rock on the glass slide and immersed in the Canadian balsam and then examined under the light microscope. Isolated forms of the studied microfossils as well as their preservation were studied. The time at which debris flows took place as well as the age and origin of fossil material, moved by debris flows were determined.

Biostratigraphic and environmental analyzes were based on taxonomical affiliation and paleoecological preferences of microfauna and nannoflora. The relationship between foraminiferal morphogroups and environment was useful in palaeoecological interpretations (Severin 1983, Jones \& Charnock 1985, Loeblich \& Tappan 1987, Meyn \& Vespermann 1994).

\section{MICROPALEONTOLOGICAL ANALYZES}

Foraminifera from the studied samples are not very numerous and often poorly preserved. Paleocene planktonic forms are: S. triloculinoides, $P$. inaequispira, $M$. angulata, $M$. velascoensis and G. velascoensis. The lastform is correlated with the latest Paleocene. They are accompanied by calcareous benthonic (Cibicidesasteroides, $C$. succedens) and agglutinated forms (B. spectabilis, $R$. fissistomata, D. retusa, G. conversa) (comp. with Morgiel 1959, Geroch \& Kotlarczyk 1963, Szczechura \& Pożaryska 1974, Morgiel \& Szymakowska 1978). Additionally, other microfossils including bryozoans and sponge spicules were noted.

The majority of the calcareous nannoplankton assemblages in the all analyzed samples from the Babica clays consisted of destroyed fragments of coccoliths. Coccolithus pelagicus (the first occurrence in the Lower Paleocene), Chiasmolithus and Cruciplacolithus species dominated in the assemblages (Figs 4, 8). Typical Paleocene species, such as Neococcolithes protenus, Neochiastozygus genus (Ne. concinnus, Ne. junctusand Ne. perfectus) and Fasciculithus (F.janii, F.pileatus, F.thomasii, F.ulii) occurred less frequently. Sphenolithus and Discoastera appeared only as single specimens. In the investigated samples, the presence of calcareous dinoflagellata (Thoracosphaera deflandrei, T. heimii, T. operculata, T. saxea) was also recorded. In high latitudes, the blooms of Thoracosphaera species were described from the lowest part of the Early Paleocene. The forms bearing the traces of damage and dissolution dominate both groups of fossils, as well as macrofauna.

Similarly, the preserved fossils were described from the Czudec clays. Foraminiferal assemblages include planktonic species of the Acarinina genus (A. primitiva, A. brodermanii, A. grave, A. bulbrooki) and the individual forms of the Turborotalia genus (T. frontosa, T. wilson), narrowing the age to the Middle Eocene. They were accompanied by forms found in the older part of the Paleogene. They are represented by planktonic taxa (S. linaperta, P. inaequispira, G. cryptomphala, G. turgida) and benthonic forms belonging to genera: Globocassidulina, Alabammina, Cibicides, Falsoplanulina, Korobkovella, Lobatula, Gyroidinoides, Hanzawaia, Pleurostomella, Bulimina, Uvigerina and Fursenkoina (Figs 5, 7). Apart from calcareous foraminifers single agglutinated forms (Spiroplectinella dalmatica) occur. In addition some specimens of ostracods (?E. macropho$\mathrm{ra}$ ) indicate in washed samples. 


\begin{tabular}{|c|c|c|c|c|c|}
\hline \multicolumn{6}{|c|}{ BABICA CLAYS } \\
\hline \multicolumn{6}{|c|}{ Połomia (Kosina stream) } \\
\hline \multirow[b]{2}{*}{$\begin{array}{l}\text { calcareous nannoplankton } \\
\text { (x) }\end{array}$} & \multicolumn{4}{|c|}{ samples } & \multirow{2}{*}{$\begin{array}{l}\text { foraminifera } \\
\text { (o) }\end{array}$} \\
\hline & $\stackrel{\infty}{\varrho}$ & $\stackrel{\infty}{\stackrel{0}{\sim}}$ & $\frac{\infty}{\infty}$ & $\begin{array}{l}\infty \\
\infty \\
\dot{\gamma} \\
\gamma\end{array}$ & \\
\hline Chiasmolithus bidens & & $\mathrm{o}$ & & $\mathrm{xO}$ & Subbotina triloculinoides \\
\hline Chiasmolithus consuetus & $\mathrm{x}$ & $\mathrm{x}$ & & x o & Parasubbotina inaequispira \\
\hline Chiasmolithus danicus & & o & & $\mathrm{x}$ & Subbotina linaperta \\
\hline Coccolithus pelagicus & $\mathrm{x}$ & $\mathrm{x}$ & $\mathrm{x}$ & $\mathrm{xo}$ & Subbotina velascoensis \\
\hline Cruciplacolithus frequens & & & & $\mathrm{xo}$ & Globigerina triangularis \\
\hline Discoaster multiradiatus & & & & x o & Globigerina trivialis \\
\hline Ericsonia cava & & & & x o & Morozovella aequa \\
\hline Fasciculithus sp. & $\mathrm{x}$ & $\mathrm{x}$ & & $\mathrm{xo}$ & Morozovella angulata \\
\hline Neochiastozygus concinnus & & & & x o & Morozovella velascoensis \\
\hline Neochiastozygus junctus & & & & $\mathrm{xo}$ & Acarinina sp. \\
\hline Neochiastozygus perfectus & & & & $\mathrm{xo}$ & Cibicides cf. asteroides \\
\hline Neococcolithe protenus & & & & xo & Cibicides succedens \\
\hline Sphenolithus primus & $\mathrm{x}$ & $\mathrm{x}$ & & o & Nuttallides trumpyi \\
\hline Thoracosphaera deflandrei & o & $\mathrm{x}$ & & & Rzehakina fissistomata \\
\hline Thoracosphaera heimii & $\mathrm{o}$ & & & $\mathrm{x}$ & Dorothia crassa \\
\hline Thoracosphaera operculata & & & o & $\mathrm{x}$ & Gerochammina conversa \\
\hline Toweius pertusus & $\mathrm{O}$ & $\mathrm{x}$ & & & Bolivinopsis spectabilis \\
\hline
\end{tabular}

Fig. 4. Distribution of foraminifera and calcareous nannoplankton in the samples of the Babica clays. The occurrence of calcareous nannoplankton $(x)$ and foraminifera (o)

The calcareous nannoplankton assemblage is dominated by the forms belonging to Coccolithus pelagicus, Ericsonia formosa and Chiasmolithus. Pontosphaera, Helicosphaera and Transversopontis species occurred less frequently. The single specimens of Sphenolithus, Discoaster, Neococcolithes, Campylosphaera and Reticulofenestra were noted (Figs 5, 8). The sediments of the Czudec clays based on calcareous nannoplankton analyzes were assigned to the Early and in the most part to the Middle Eocene.

Samples collected from the Popiele beds contain calcareous nannoflora and microfauna including mainly species, which are known from the Globigerina marls (Garecka et al. 2008). A typical calcareous nannoplankton associations was composed of: Clausicoccus subdistichus, Isthmolithus recurvus, Lanternithus minutus, Reticulofenestra lockeri, $R$. ornata, $R$. umbilica, which indicate the Early Oligocene age (Figs 6, 7) while foraminifers consist mainly of species from the Late Eocene and the Eocene-Oligocene transition (Globigerina praebulloides, G. ouachitensis, Subbotina angiporoides, S. transdanubica, Globoquadrina tripartita, Catapsydrax dissimilis, C. perus, C. primitivus, Cibicides amphisylensis, C. lopjanicus). Among them, the calcareous benthonic (Cibicides, Melonis, Hansenisca, Uvigerina, Lenticulina, Globobulimina, Nodosaria) and occasionally agglutinated forms (Clavulinoides, Bolivinopsis) were also noted (Figs 6, 8). Some of them are redeposited. In addition, other benthonic forms belonging to genera: Almaena, Spiroplectamina, Brizalina, Nonion, Asterigerina, Alabamina, Valvulineria, Trifarina, and plankton taxa of Globigerinatheka and Turborotalia are also known from these deposits (Rajchel 1990).

In the calcareous nannofossils assemblage there was no presence of these species whose last evolutionary occurrence took place in the Latest Eocene and in the lowest part of the Lower Oligocene. 
CZUDEC CLAYS

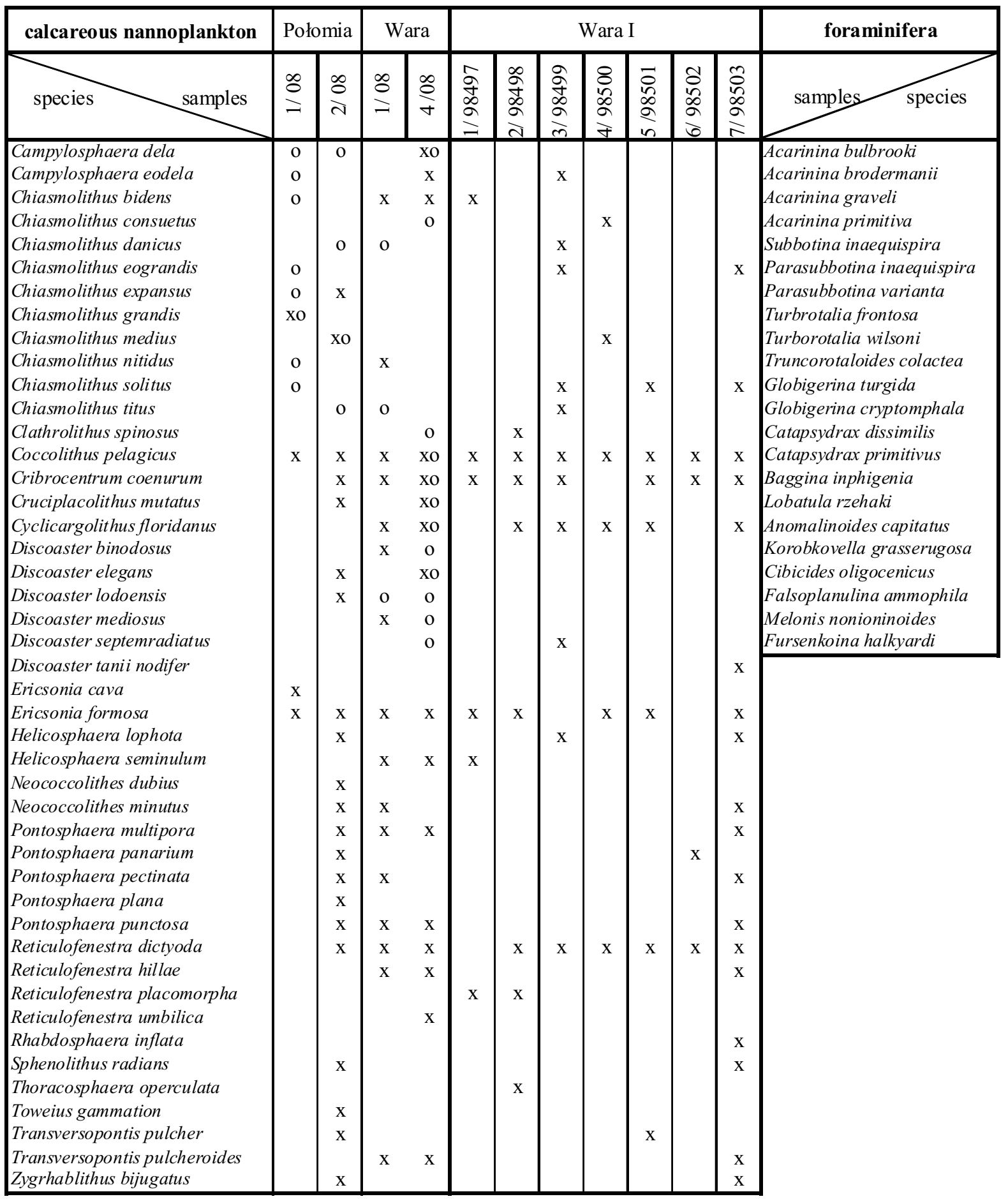

Fig. 5. Distribution of foraminifera and calcareous nannoplankton in the samples of the Czudec clays. The occurrence of calcareous nannoplankton $(x)$ and foraminifera (o)

Apart from the Eocene-Oligocene species, the occurrence of the Early Oligocene (the first documented occurrence in the upper part of the NP21 and NP22 Calcareous Nannoplankton
Zones) R. lockeri, R. ornata and C. subdistichus were recorded (Jurašova 1974, Nagymarosy \& Báldi-Beke 1988, Smoleńska \& Dudziak 1989, Nagymarosy \& Voronina 1992, Garecka 2005, 2008). 


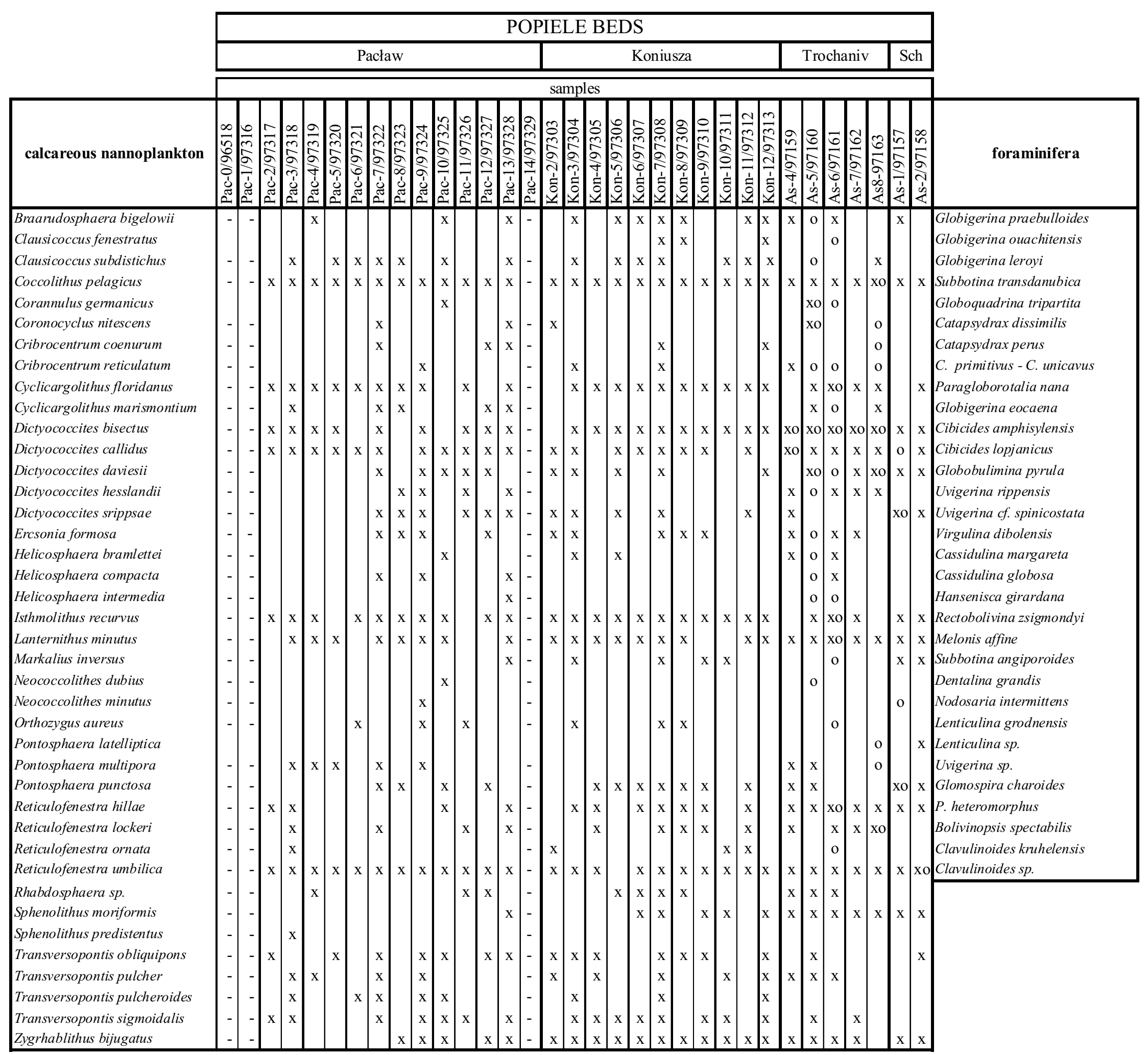

Fig. 6. Distribution of foraminifera and calcareous nannoplankton in the samples of the Popiele beds. The occurrence of calcareous nannoplankton ( $x$ ) and foraminifera (o) 

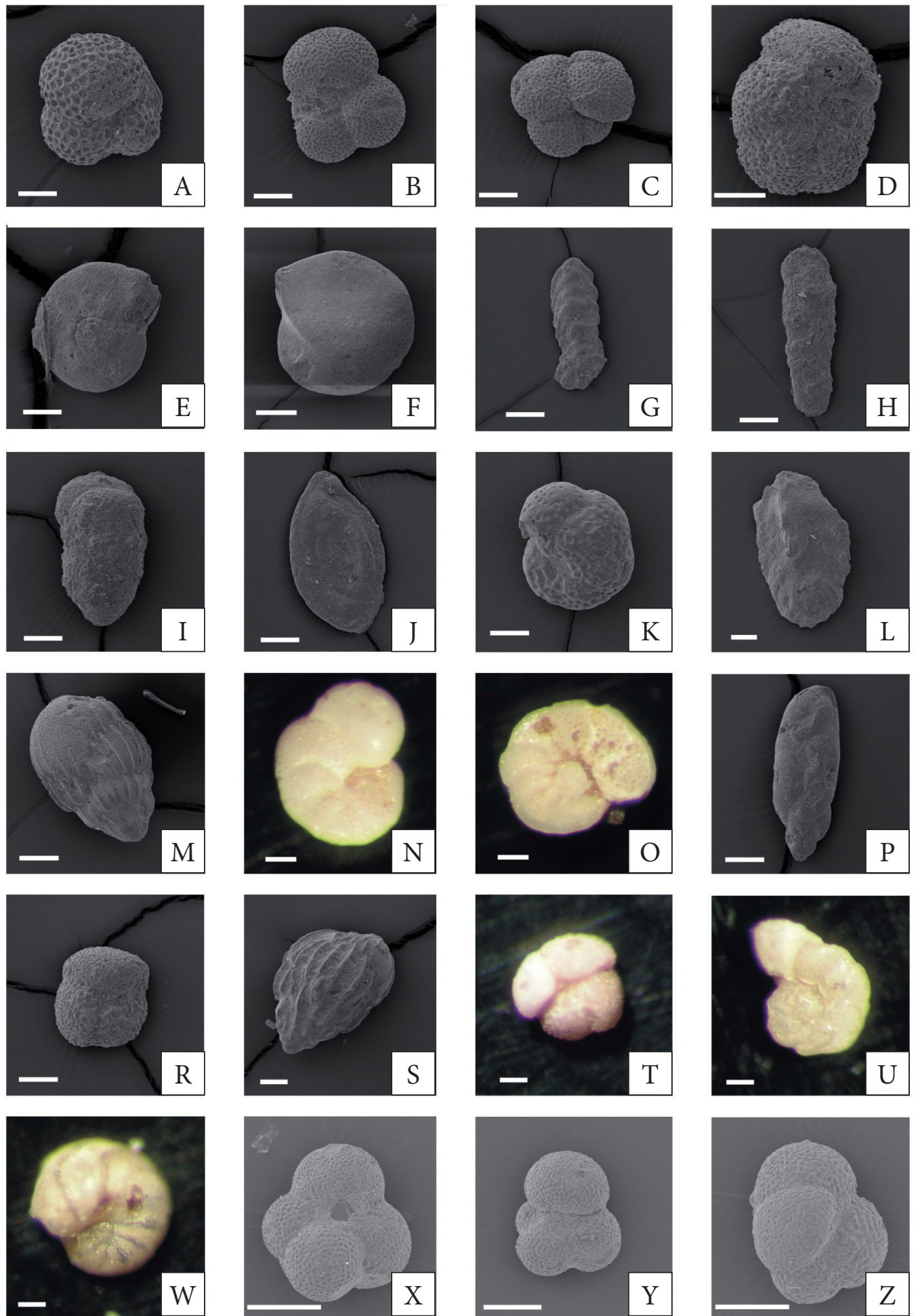

Fig. 7. Selected foraminifera from studied deposits. Babica clays (Połomia): A) Subbotina triloculinoides (Plummer); B) Parasubbotina inaequispira (Subbotina); C) Globigerina triangularis White; D) Morozovella angulata (White); E) Cibicides cf. succedens Brotzen; F) fragments of the snails shell; G) Bolivinopsis spectabilis (Grzybowski); H) Gerochammina conversa (Grzybowski); I) Dorothia retusa (Cushman); J) Rzehakina fissistomata (Grzybowski); Czudec clays (Wara): K) Anomalinoides capitatus (Gümbel); L) Spiroplectinella dalmatica (de Witt Payt); M) Uvigerina costellata Morozova; N) Korobkovella grasserugosa (Gümbel); O) Cibicides oligocenicus Samoilova; P) Fursenkoina halkyardi (Cushman); R) Acarinina primitiva (Finlay); S) Bulimina cf. subtruncana Hagn; T) Acarinina bulbrooki (Bolli); U) Lobatula rzehaki (Grzybowski); W) Falsoplanulina ammophila (Gümbel); Popiele beds (Trochaniv): X) Globigerina ouachitensis Howe and Wallace; Y) G. praebulloides leroyi Blow \& Banner; Z) Catapsydrax prmitivus (Blow \& Banner). Scale: $100 \mu \mathrm{m}$ 

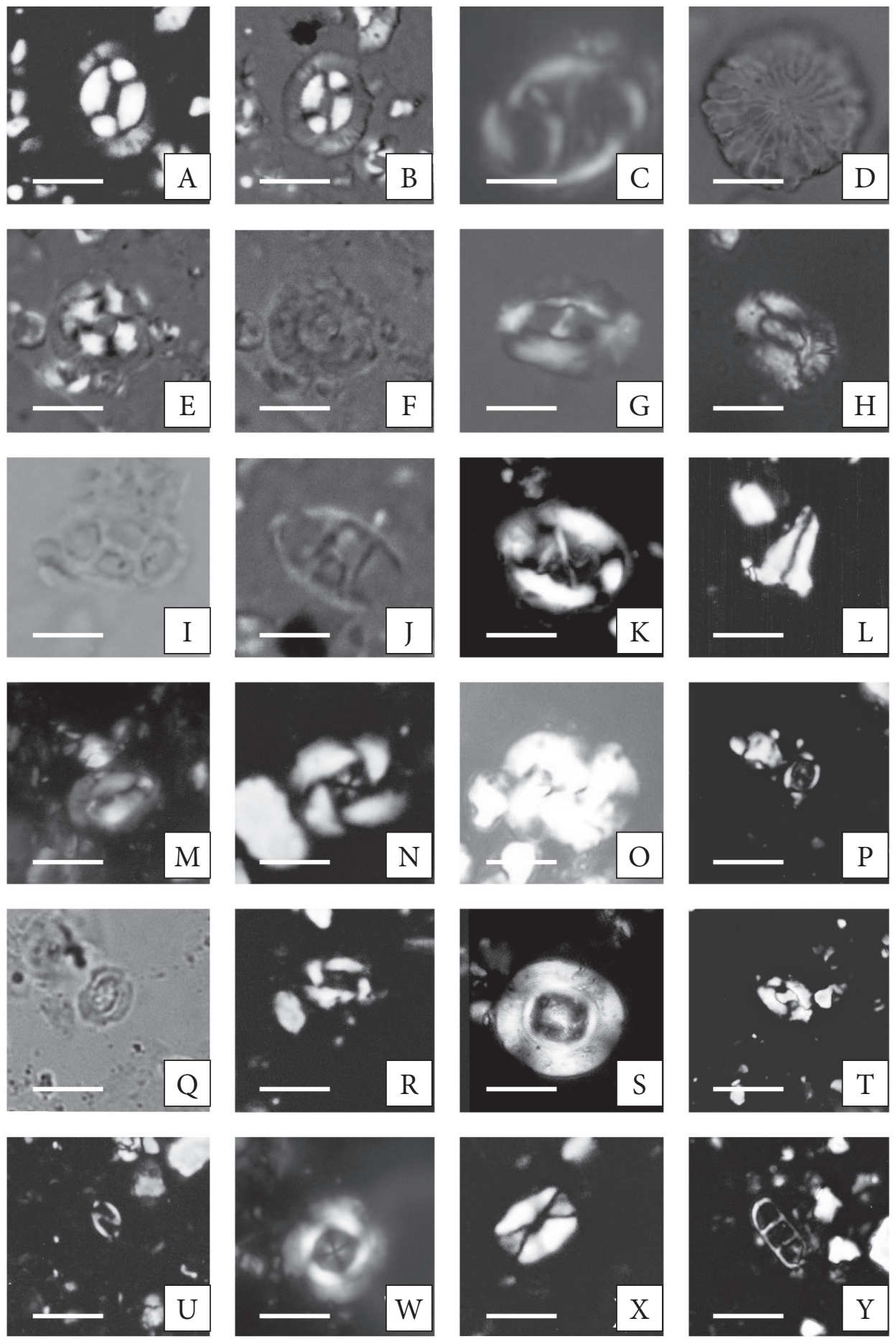

Fig. 8. Selected calcareous nannoplankton from studied deposits. Babica clays: A) Coccolithus pelagicus (Wallich) Schiller (CN); B) C. pelagicus (Wallich) Schiller (NL); C) Neochiastozygus perfectus Perch-Nielsen (CN); D) Discoaster multiradiatus Bramlette et Riedel; Czudec clays: E) Ericsonia formosa (Kamptner) Haq (CN); F) E. formosa (Kamptner) Haq (NL); G) Helicosphaera seminulum Bramlette et Sullivan (CN); H) Helicosphaera lophota Bramlette et Sullivan (CN); I) Neococcolithes dubius (Deflandre) Black (NL); J) Neococcolithes minutus (Perch-Nielsen) Perch-Nielsen (NL); K) Chiasmolithus solitus(Bramlette et Sullivan) Locker (CN); L) Zygrhablithus bijugatus (Deflandre) Deflandre (CN-0 ${ }^{\circ}$; Popiele beds: M) Helicosphaera compacta Bramlette et Wilcoxon (CN), Trochaniv; N) Cribrocentrum reticulatum (Gartner et Smith) Perch-Nieslen (CN), Trochaniv; O) Dictyococcites bisectus (Hay, Mohler et Wade) Bukry et Percival (CN), Pacław; P) Clausicoccus subdistichus (Roth et Hay) Prins (CN), Pacław; Q) Cl. subdistichus (Roth et Hay) Prins (NL), Pacław; R) Reticulofenestra lockeri Müller (CN), Trochaniv; S) Reticulofenestra umbilica (Levin) Martini \& Ritzkowski (CN), Koniusza; T) Helicosphaera bramlettei Müller (CN), Trochaniv; U) Transversopontis obliquipons (Deflandre) Hay, Mohler et Wade (CN), Koniusza; W) Dictyococcites callidus Perch-Nielsen (CN), Pactaw;X) Lanternithus minutes Stradner (CN), Trochaniv; Y) Isthmolithus recurvus Deflandre (CN), Pacław, NL - normal light, CN - crossed nicols. Scale: 5 um 


\section{DEPOSITIONAL ENVIRONMENTS}

Sediments reworked by gravity flows and olistostromes include fossils and rock blocks (bioclasts) that were identified and described previously (Książkiewicz 1958, Morgiel \& Gucik 1965, Dżułyński \& Kotlarczyk 1967, Szymakowska 1976, Morgiel \& Szymakowska 1978, Kotlarczyk 1981) as well as during the present studies. They include shallow-water and calcareous forms, which refer to source areas located on the periphery and inside the Carpathian basins. In the Paleogene, slopes and inner basin ridges were affected by mass movements activities. Submarine landslides, which evolve into gravity flows, debris and mud flows in the upper part of the slope (cohesive flows) and turbidity currents in the distal parts of the basin (suspension) belong to these activities. A number, state of preservation, and distribution of fossils from the studied sediments indicate the intensity, pattern and duration of transport during the gravitational processes. In addition, the variety among species of fossils allows fot the documenting of the time of the final deposition of sediment transported on the slope. The effects of physical (transport, erosion, mechanical deformation or disintegration), chemical (dissolution, diagenesis), and biological factors (decomposition of the body, bioerosion, bioturbation) on the behavior of the organic remains and their fossilization (mechanical, chemical and mineralogical changes including pyritization, calcification) manifested itself in their taphonomy. It seems that benthonic foraminifera best document the sediments. They are indispensable in the reconstruction of the paleoenvironment, accurately dating the final moment of redeposition. Benthonic foraminifers, closely related to the sediment, are preserved much better than the fossilized foraminiferal plankton and calcareous nannoplankton, more susceptible to mechanical damage and dissolution. Generally, the microfossils in cohesive flows were often mechanically deformed and broken but at the same time protected perhaps from dissolution (Fig. 9).

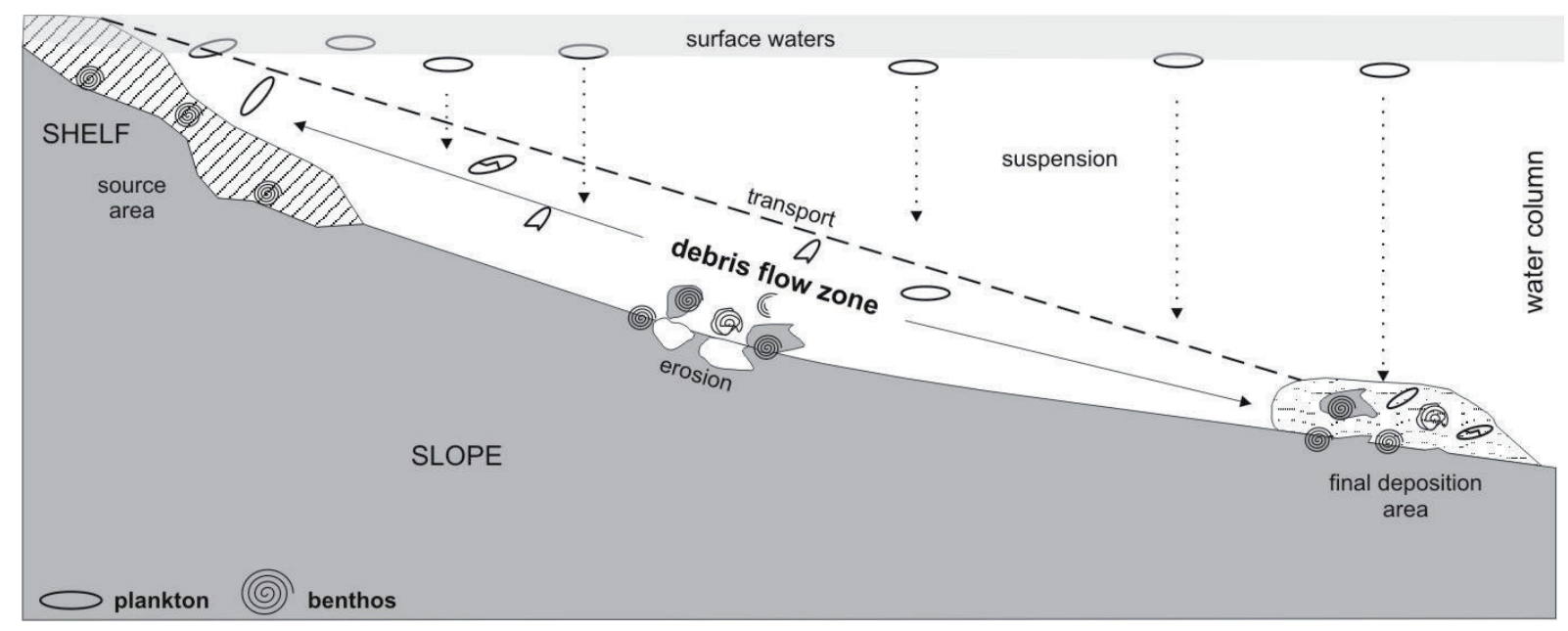

Fig. 9. The origin, distribution and taphonomic features of microfossils from the sediments formed by debris flow

The displacement and preservation at the greater depths was also observed in the shells and fecal pellets. Therefore, it happens that in the sediments moved down slope, both fossil forms resistant for the dissolution and species sensitive for environmental changes appear. The first group includes thick-walled foraminifera (Acarinina, Morozovella) and calcareous nannoplankton (Coccolithus, Chiasmolithus, Cruciplacolithus, Dictyococcites and Reticulofenestra) while the second is represented by small and thin-walled Subbotinaand Globigerina or delicate plates of calcareous nannoplankton (i.a. holococcoliths, pentaliths, cribriliths). Additionally, coccoliths and foraminiferal shells are numerous and widespread in the studied deposits. They belong to microorganisms, which are resistant and tolerate chemical factors and changes in the water environment. It is a result of chemical and biological features, inner structure and arrangement of the skeletal parts in 
the cells (Báldi-Beke 1984, Nguyen et al. 2011). In consequence of the high potential of adaptation and fossilization, foraminifera and calcareous nannoplankton are useful for the reconstruction of depositional environments, in which the sediments were originally accumulated and then transported and finally deposited. These suggestions were supported by fossils found in the Skole series of the Polish and Ukrainian Outer Carpathians. This is particularly evident in the case of sediments deposited in the Paleogene.

At this time, within the Skole basin, the Babica clays were deposited by submarine landslides (for example Połomia, Kosina stream). They contain numerous diverse groups including plankton (Globigerina, Morozovella, Subbotina) and calcareous benthonic epifauna (Gyroidinoides, Osangularia, Cibicides, Valvulineria, Rotaliano, Asterigerina, Cibicidoides) and infauna (Lenticulina), whose calcareous shells are usually corroded, broken, and even sometimes dissolved, leaving behind only interior casts (comp. with Szczechura \& Pożaryska 1974, Morgiel \& Szymakowska 1978). The frequent accumulations of shell clams and snails are also known from these clays, usually bearing clear signs of damage. In these deposits, also olistoliths and exotics tens of centimeters in diameter occur. In contrast to the above-mentioned sediments of the olistostrome type, which were displaced from the shelf of the Skole basin during the Paleocene times, the Eocene Czudec clays (Wara locality) occurring within the Hieroglyphic beds are characterized by a greater share of mudstone, only occasionally containing clasts of marls and small olistoliths. Fossil material from these clays includes the foraminiferal plankton represented by the Early Eocene genera: Turborotalia, Acarinina, Morozovella and deep infauna (Virgulina, Uvigerina, Anomalinoides, Bulimina), deposited in the lower part of the slope. Some of them, displaying unornamented shell lived in poorly oxygenated waters (Bernhard 1986), which caused the dark color of the sediments.

The state of preservation of coccoliths, their abundance and diversification of the species in the sediment were affected by different physical and chemical processes that caused their destruction, dilution and dissolution during the fall to the sea bottom. The coccoliths from the Babica clays are predominated represented by badly preserved, crumbled fragments of undistinguishable forms. The assemblage consisted of most resistant placoliths represented by Coccolithus pelagicus. The cool or even cold water massive Chiasmolithus species occurred less frequently. The second overgrown (the central area which is a diagnostic element of the species is completely infilled or empty) excluded the identification of these forms. Sometimes, only the external parts of the coccoliths plates (without central structures) were preserved. Zygodiscaceae (Neochiastozygus and Neococcolithes species) and diagnostic for the Paleocene Fasciculithaceae are saved as fragments or show signs of second recrystallization. The open marine Discoaster and Sphenolithus occurred as single specimens only. More diversified assemblage was described from the Czudec clays. Among the mentioned above forms, the warm, shallow water Helicosphaera species (with co-occurrence Pontosphaera and Transversopontis species) occurred. Generally, it seems that both the Paleocene (Babica clays) and Eocene (Czudec clays) materials were mixed and included forms typical respectively for the early and late Paleocene as well for the Eocene (Figs 4, 5). During this time-interval, sea-level fluctuations and climate changes influenced migrations and radiations of fauna. Some of them, especially the calcareous forms, were similar to these known from shallow-water environments located within the platform areas of the Polish Lowlands (Krach 1969, Szczechura \& Pożaryska 1974). The same relationship is also visible in the deposits of the Czudec clays and Popiele beds.

Calcareous microfauna from the Eocene-Oligocene times was documented in the Popiele beds (Pacław, Koniusza, Schodnica, Trochaniv), which represent deposits of the olistostrome type deposited in the proximal environments. Assemblages including calcareous foraminifera occur in them unevenly, and are represented by a variety of planktonic species belonging to genera: Globigerina and Catapsydrax. They are accompanied by various calcareous benthonic forms belonging to epifauna (Hansenisca, Cibicides), shallow (Dentalina) and mobile (Lenticulina, Melonis, Cassidulina) and also deep infauna (Rectobolivina, Globobulimina, Uvigerina), which bears signs of mechanical damage and mineralogical changes 
(pyritization). This benthosis represented mainly by calcareous ornamented shells, which are typical for well-oxygenated environments. However, the presence of the planktonic forms with additional chamber (bulla) and the calcareous benthonic foraminifers whose shells were pyritized, suggests that the final deposition took place in the hostile environment because the supply of oxygen was quickly reduced during the deposition of the clastic material forming the Hieroglyphic sandstones. In addition, calcareous benthonic forms (Cibicides, Melonis, Hansenisca, Uvigerina, Lenticulina, Globobulimina, Brizalina, Globobulimina) and agglutinated taxa (Clavulinoides) refers to the original environment of deposition in the upper part of a slope. In the calcareous nannoplankton assemblages, the most resistant, long-ranging placoliths (Coccolithus, Dictyococcites) and Reticulofenestra species dominated. The other species occurred less frequently (Isthmolithus, Lanternithus, Clausicoccus) or sporadically (Pontosphaera, Helicosphaera, Discoaster and Zygrhablithus). The large, massive forms such as Reticulofenestra umbilica, Dictyococcites bisectus and forms of simple structure (Isthmolithus recurvus) are badly preserved. Mechanical deformation (breakage, fragmentation and fracture of the plates) dominated. The secondary recrystallization and corrosion observed in the assemblages from the Popiele beds played a subsidiary role. These processes affected mainly forms belonging to holococcoliths (Lanternithus minutus, Zygrhablithus bijugatus) and large specimens mentioned above. In occurring sporadically discoasters and pentaliths (Braarudosphaeraspecies) the corrosion processes are clearly marked (etching of the plates, dissolved arms). The dominant forms are represented mainly by temperate (R. umbilica, D. bisectus), cool water (R. lockeri, $R$. ornata, D. callidus, I. recurvus) and cosmopolitan species (Coccolithus pelagicus, Cl. subdistichus, L. minutus). The warm water species occurred infrequently or were absent. The occurrence of these species is restricted to the outer shelf areas. Some of them (D. bisectus, L. minutus and I. recurvus) prefer more near-shore facies. The composition of the calcareous nannoplankton and foraminifers assemblages are similar to those known from the Globigerina marls. It seems that the formation of the Popiele beds took place simultaneously with the deposition of Globigerina marls during the same episode.

\section{DISSCUSSION}

During the Paleogene, the cohesive flows in more proximal parts of basin occurred with greater intensity and more frequently in the external Skole region than in other more internal zones of the Outer Carpathians (Subsilesian-Silesian and Dukla zones). Deposits formed predominantly by debris flows are exposed mainly in the foothills of the Eastern Carpathians (Poland, Ukraine) in the structures of the Skole unit, and very rarely occur in successions of the Silesian and the Subsilesian units in the North-Eastern Outer Carpathians in Poland and Ukraine (Ślączka \& Kaminski 1998, Szydło 2011). It is a consequence of geotectonic evolution of this area and the gradual closing of the Outer Carpathians basins. These external settings resulted in Eustatic fluctuations, which were correlated with supplies of clastic material into the Skole basin. The morphological diversity of this basin impacted the development and preservation of carbonate sediments and fossil material occurring within the analyzed sediments. In marine environments, the relative movements of the sea surface indicate the two types of processes: erosion and corrosion of the bottom sediments (Haq 1993). The erosion of bottom sediments is associated with a decrease of the sea level resulting in increased weathering affecting the increased supply of carbonate and siliceous clastic land material. The distribution of this material at the bottom of the sea enriched the water nutrients enhancing the development of the organic world. An increased share of carbonates on the seafloor resulted in lower compensation of calcium carbonate (change of the CCD) and total deposition of carbonates in the basin. The corrosion (dissolution) of the bottom sediments, including hemipelagic sediments rich in the pelagic organisms during the transgression is associated with poor differentiation of thermal water and drop in bottom-water activity. During this time, at the bottom of the basin, the dissolution of carbonates conducive to raising the limit of the CCD increased. Exposing and destroying 
shelf environments during transgressive-regressive periods and deepening the basin were associated with the development of submarine landslides involving gravity slides, which transformed often into olistostrome complexes. These complexes represent different types of sediment gravity flows (Nelson 2012). Their types and distribution in the basin indicate the distance between the source and depositional areas. The source area was located on shelves and elevations. The carbonate sediments were transiently accumulated in their redeposition zones, located on a slope and rise parts of the basin (Piper et al. 1999). In general, the submarine landslides could be replaced already in the upper part of the slope and then underwent transformation moving further along the slope. More water-saturated sediment were diffused, transported in the flows of varying density or dropped from turbidity currents on the basin's slope and rise.

The distribution of the analyzed sediments in the Carpathian basin is related to its geotectonic development. Their location in the studied area reflects the changes in the geomorphology of the basin, the location and migration of the centers of deposition and the rate and nature of deposition. In contrast to the Mesozoic, submarine mass movements affecting the supply of sediments from shelves in the Paleogene times, occurred more frequently in the Skole basin than in the Silesian basin, with the turbidite deposition of the Istebna and Ciężkowice beds (Nescieruk \& Szydło 2003, Felix et al. 2009). At this time, marly sediments formed within the Subsilesian, while on the slope of the Skole basin rock material was moved mainly in the form of a debris flow, which reached the area of turbidite sedimentation of the Inoceramus (Babica clays) and Hieroglyphic beds (Czudec clays). In addition, at the turn of the Eocene and Oligocene, submarine landslides (Popiele beds, which lie between the Hieroglyphic beds and Menilite shales) were formed, involving rock blocks of different size (Rajchel 1990).

Part of this sediment was fragmented. Theses shallow-water sediments contain rock blocks, slides. They appear often in the form of lenses of laminated and semi-fluid rock. The material was moved. The movements distance was significant, but shorter than in the case of turbiditic currents.
The presence of such multiple resediments evidenced intense shortening of the Skole basin in the Late Paleogene times and the existence of tectonically unstable areas of shallow water sedimentation. After this period, the re-unification and a decrease in the rate of deposition in the Carpathian basin (high-stand) favored the pelagic sedimentation of the Globigerina marls, which in the early Oligocene was replaced by the deposition of bituminous Menilite shales following the shortening of the basin and a sudden drop in sea level (Haq et al. 1988). The flows include the organic components from shallow shelf environment (Olszewska 1984, 1985). The pyritized benthonic microfauna present in the series is associated with the slope of the basin. The flows including exotics were deposited from the beginning to the end of the development of the Carpathian basins, which underwent gradual remodeling leading to its closure in the Early Miocene times (Kotlarczyk 1981, Oszczypko 1998).

The researcher, analyzing the scale of the development of mass movements in the Carpathian basins expects the existence of the tectonically unstable areas of shallow water carbonate sedimentation, which were rebuilt and destroyed during geotectonic and geodynamic transformation. The frequency of fossil material in the shallow flysch successions clearly show the relatively small distance between the source and accumulation areas, which could occur only in not too large basin. Event-driven nature of the studied sediments, the relatively small thickness and susceptibility to weathering and erosion processes probably contributed to the scale and frequency of their occurrence in the flysch successions, which because of their stratigraphic range sometimes masked these redestributed deposits (Fig. 9). Additionally, fossil assemblages yielded by the deposits, especially mollusks, foraminifers and bryozoans corresponded to shallow water sedimentation on platform areas located in the transition province between these biogeographic areas (Blaicher \& Sikora 1967, Scheibnerova 1971).

\section{CONCLUSIONS}

The sedimentologic nature and the micropaleontological content of the studied deposits from the Paleogene flysch of the Skole unit determine 
their origin and age. These deposits were transported down slope by sediment gravity flows of high concentration (debris flows) and finally accumulated in the Paleocene (Babica clays), Middle Eocene (Czudec clays) and Lower Oligocene (Popiele beds, local mudstones layers in the Menilite-Krosno series) rocks. During this process, sediments originally accumulated in the upper part of the slope were liquefied and were carried in suspension down the slope. They pass through various environments and annex the micropaleontological forms, which came from the eroded slopes material and those present in the water column. In consequence, deposits formed by debris flows contain mixed assemblages including forms of different age and coming from varied environments. Foraminifers reflect environmental settings and document the process of erosion while calcareous nannoplankton is more useful for determining the time of final deposition on a slope. In both groups, recycled forms are frequent and sometimes better preserved than the forms that were present during these events in the basin. These features of fossil assemblages document the submarine processes and the degree of redeposition of the material transported by debris flows. Moreover, they indicate the areas where rock material originated. The dominance of calcareous fossils in reworked material reflect more proximal and shallower environments, which were destroyed during the geotectonic transformation of the Skole sub-basin in the Paleogene. However, it is difficult to find the record of this transformation in flysch, which typically reach several thousand meters. The sediments containing these displaced and poorly preserved fossils appear in the local rocks with a relatively small thickness.

The authors wish to thank all those involved in the review of this paper. The presented study is a part of research financially supported by the Polish Ministry of Science and Higher Education (grant no. N307 $00532 / 0230$ ).

\section{REFERENCES}

Barber J.R., 2010. Elasticity. Solid Mechanics and Its Applications, 172, 91-108.

Báldi-Beke M., 1984. The nannoplankton of the Transdanubian Palaeogene formations. Geologica Hungarica, 43, $1-307$.
Bernhard J.M., 1986. Characteristic assemblages and morphologies of benthic foraminifera from anoxic, organic-rich deposits: Jurassic through Holocene. Journal of Foraminiferal Research, 16, 3, 207-215.

Blaicher J. \& Sikora W., 1967. Mikrofaunisticeskie associacii paleogena polskich flisevych Karpat. VIII Carpatho-Balkan Geological Association Congress, Belgrade, Serbia, 363-366.

Bukowy S. \& Geroch S., 1957. O wieku zlepieńców egzotykowych w Kruhelu Wielkim. Rocznik Polskiego Towarzystwa Geologicznego, 26, 4, 297-329.

Bukry D., 1981. Cenozoic coccoliths from the Deep Sea Drilling Project. [in:] Warme J.E., Douglas R.G. \& Winterer E.L. (eds), The Deep Sea Drilling Project: A decade of Progress, Society of Economic Paleontologists and Mineralogists, Tulsa, Special Publication, 32, 335-353.

Dasgupta P., 2003. Sediment gravity flow-the conceptual problems. Earth-Science Reviews, 62, 265-281.

Dżułyński S. \& Kotlarczyk J., 1965. O pochodzeniu warstw popielskich w Karpatach polskich. Rocznik Polskiego Towarzystwa Geologicznego, 35, 1, 103-105.

Dżułyński S., Książkiewicz M. \& Kuenen Ph.H., 1959. Turbidites in flysch of the Polish Carpathians. Bulletin of the Geological Society of America, 70, 1089-1118.

Dżułyński S., Kotlarczyk J. \& Ney R., 1979. Podmorskie ruchy masowe w basenie skolskim. [in:] Kotlarczyk J. (red.), Stratygrafia formacji z Ropianki (fm): poziomy z olistostromami w Karpatach przemyskich: materialy terenowej konferencji naukowej w Przemyślu [Krajowej Konferencji Sedymentologów] Przemyśl, 28-29 czerwca 1979 r., 17-27.

Erba E., 2006. The first million years history of calcareous nannoplankton: Biosphere-geosphere interactions. $\mathrm{Pa}$ laeogeography, Palaeoclimatology, Palaeoecology, 232, 237-250.

Felix M. \& Peakall J., 2006. Transformation of debris flows into turbidity currents: mechanisms inferred from laboratory experiments. Sedimentology, 53, 107-123.

Felix M., Leszczynski S., Ślączka A., Uchman A., Amyc L. \& Peakalla J., 2009. Field expressions of the transformation of debris flows into turbidity currents, with examples from the Polish Carpathians and the French Maritime Alps. Marine and Petroleum Geology, 26, 2011-2020.

Garecka M., 2005. Calcareous nannoplankton from the Podhale Flysch (Oligocene-Miocene, Inner Carpathians, Poland). Studia Geologica Polonica, 124, 353-369.

Garecka M., 2008. Granica oligocen/miocen w polskich Karpatach zewnętrznych na podstawie nanoplanktonu wapiennego. Biuletyn Państwowego Instytutu Geologicznego, 432, 1-54.

Garecka M., Jankowski L. \& Szydło A., 2008. Spływowe osady paleogenu wschodniej części Karpat zewnętrznych w strefie przygranicznej Polski i Ukrainy. [in:] Haczewski G. (red.)., Pierwszy Kongres Geologiczny, Kraków 26-28 czerwca 2008. Abstrakty, 28-29.

Geroch S., Jednorowska A., Książkiewicz M. \& Liszkowa J., 1967. Stratigraphy based upon microfauna in the Western Polish Carpathians. Biuletyn Instytutu Geologicznego, 211, 185-267.

Golonka J., Oszczypko N. \& Ślączka A., 2000. Late Carboniferous-Neogene geodynamic evolution and paleogeography of the circum-Carpathian region and 
adjacent areas. Annales Societatis Geologorum Poloniae, 70, 113-116.

Gradstein F.M. \& Ogg J.G., 2004. Geologic time scale 2004 - Why, how, and where next. Lethaia, 37, 175-181.

Gucik S. \& Morgiel J., 1965. Les dépôts du Crétacéinférieur et supérieurdans les Maastrichtien de l'unité de "skibas" les Karpates polonaises. VIII Carpatho-Balkan Geological Association Congress, Belgrade, Serbia Congress Reports, II, 2, 73-76.

Hampton M.A., 1972. The role of subaqueous debris flow in generating turbidity currents. Journal of Sedimentary Petrology, 42, 775-793.

Haq B.U., Hardenbol J. \& Vail P.R., 1988. Mesozoic and Cenozoic chronostratigraphy and cycles of sea-level change. SEPM Special Publications, 42, 71-108.

Jankowski L., Kopciowski R. \& Ryłko W. (eds), 2004. Geological Map of the Outer Carpathians: Borderlands of Poland, Ukraine and Slovakia: 1:200 000. Polish Geological Institute, Warsaw.

Johnson A.M. \& Rodine J.R., 1984. Debris flow. [in.:] Brundsen D. \& Prior D.B. (eds), Slope Instability, Wiley, Chichester, 257-361.

Jones R.W. \& Charnock M.A., 1985. "Morphogroups" of agglutinated foraminifera. Their life positions, feeding habits and potential applicability in (paleo)ecological studies. Revue de Paléobiology, 4, 2, 311-320.

Jurášova F., 1974. Nannoplankton from the Menilite Formation (Lower Oligocene) at DolniTěšice. Věstnik Ústředniho ústawu geologického, 49, 91-96.

Kotarba M.J. \& Koltun Y.V., 2006. The origin and habitat of hydrocarbons of the Polish and Ukrainian Parts of the CarpathianProvince. [in:]: Golonka J. \& Picha F.J. (eds), The Carpathians and their foreland: geology and hydrocarbon resources, AAPG Memoir, 84, 395-442.

Kotlarczyk J., 1978. Stratygrafia formacji z Ropianki (fm), czyli warstw inoceramowych w jednostce skolskiej Karpat fliszowych [Stratigraphy of the Ropianka Formation or of Inoceramian beds in the Skole Unit of the Flysch Carpathians]. Prace Geologiczne - Polska Akademia Nauk. Oddziat w Krakowie. Komisja Nauk Geologicznych, 108, 1-82 [with English summary].

Kotlarczyk J., 1979. Uwagi o wieku margli bakulitowych (margli z Węgierki) w świetle formalnej rewizji oznaczeń fauny głowonogów i inoceramów. Sprawozdania $z$ Posiedzeń Komisji Naukowych PAN Kraków, VII-XII 1977, 103-105.

Kotlarczyk J., 1981. The youngest olistostrome in the flysch deposits of the Skiba nappe (Polish Outer Carpathians). Congress of the Carpatho-Balkan Geological Association, September, 8-13, 1981, Bucharest, Romania, 263-270.

Kotlarczyk J., 1988. Geologia Karpat przemyskich - „szkic do portretu". Przegląd Geologiczny, 6, 325-333.

Kotlarczyk J. \& Leśniak T., 1990. Dolna część formacji menilitowej $z$ poziomem diatomitów $z$ Futomy $w$ jednostce skolskiej polskich Karpat [Lower part of the menilite formation and related Futoma diatomite member in the Skole unit of the Polish Carpathians]. Wyd. AGH, Kraków, 1-74.

Kotlarczyk J. \& Uchman A., 2012. Integrated ichnology and ichthyology of the Oligocene Menilite Formation, Skole and Subsilesian nappes, Polish Carpathians: A proxy to oxygenation history. Palaeogeography, Palaeoclimatology, Palaeoecology, 331-332, 104-118.

Krach W., 1969. Mollusca of the Babica clays (Paleocene) of the Middle Carpathians. Part 2: Pelecyphoda. Studia Geologica Polonica, 29, 7-79.

Krach W. \& Liszka S., 1961. Górnoeoceńska fauna z Bukowca [Upper-Eocene Fauna from Bukowiec]. Rocznik Polskiego Towarzystwa Geologicznego, 31, 1, 145-158.

Kruglov S.S., 1989. Geodynamics of the Ukrainian Carpathians. Geologica Carpathica, 40, 101-123.

Książkiewicz M., 1958. Osuwiska podmorskie we fliszu karpackim [Submarine slumping in the Carpathian Flysch]. Rocznik Polskiego Towarzystwa Geologicznego, 28, 2, 123-150.

Lee H.J., Locat J., Desgagnés P., Parsons J.D., McAdoo B.G., Orange D.L., Puig P., Wong F.L., Dartnell P. \& Boulanger E., 2007. Submarine mass movements on continental margins. [in:] Nittrouer Ch.A. et al. (eds), Continental Margin Sedimentation: From Sediment Transport to Sequence Stratigraphy, Special Publication of the IAS, 37, 213-274.

Loeblich A.R. \& Tappan H., 1987. Foraminiferal Genera and Their Classification. Van Nostrand Rienhold, New York.

Malata T., 1996. Analiza formalnych wydzieleń litostratygraficznych oraz propozycja

podziału jednostki skolskiej polskich Karpat fliszowych. Przegląd Geologiczny, 44, 5, 509-513.

Meyn H. \& Vespermann J., 1994. Taxonomische Revision von Foraminiferen der Unterkreide SE-Niedersachsens nach Roemer (1839, 1841, 1842), Koch (1851) und Reuss (1863). Senckenbergiana letizaea, 74, 49-272.

Middleton G.V. \& Hampton M.A., 1973. Sediment gravity flows: Mechanics of flow and deposition. [in:] Middleton G.V. \& Bouma A.H. (eds), Turbidites and deep-water sedimentation: lecture notes for a short course, SEPM Pacific Section, Los Angeles, 1-38.

Morgiel J. \& Szymakowska F., 1978. Stratygrafia paleocenu i eocenu jednostki skolskiej. Biuletyn Instytutu Geologicznego, 310, 39-71.

Mulder T. \& Cochonat P., 1996. Classification of off shore mass movements. Journal of Sedimentary Research, 66, 43-57.

Nagymarosy A. \& Báldi-Beke M., 1988. The position of the Paleogene formations of Hungary in the standard nannoplankton zonation. Annales Universitatis Scientiarum Budapestinensis de Rolando Eotvos Nominatae Sectio Geologica, 28, 3-25.

Nagymarosy A. \& Voronina A.A., 1992. Calcareous nannoplankton from the Lower Maykopian Beds (early Oligocene, Union of independent states). Knihovniča ZPN, $14 \mathrm{~b} / 2,189-221$.

Nelson S.A., 2012. Mass-Wasting and Mass-Wasting Processes. [online:] http://www.tulane.edu/ sanelson/Natural_Disasters/masswastproc.htm [access: 9.07.2012].

Nescieruk P. \& Szydło A., 2003. Rozwój i pozycja stratygraficzna warstw istebniańskich w Beskidzie Morawsko-Śląskim. Sborník vĕdeckých prací Vysoké školy báňské, 49, 74-75.

Nguyen T.M.P., Petrizzo M.R., Stassen P. \& Speijer R., 2011. Dissolution susceptibility of Paleocene-Eocene planktic foraminifera: Implications for palaeoceanographic 
reconstructions. Marine Micropaleontology, 81, 1-2, $1-21$.

Norem H., Locat J. \& Schieldrop B., 1990. An approach to the physics and the modelling of submarine flowslides. Marine Geotechnology, 9, 93-111.

Olszewska B., 1984. Interpretacja paleoekologiczna otwornic kredy i paleogenu polskich Karpat Zewnętrznych [A paleoecological interpretation of the Cretaceous and Paleogene foraminifers of the Polish Outer Carpathians]. Biuletyn Instytutu Geologicznego, 346, 7-53 [with English summary].

Olszewska B. 1985. Otwornice warstw menilitowych polskich Karpat zewnętrznych [Foraminifera of the Menilite Beds (Polish External Carpathians)]. Roczniki Polskiego Towarzystwa Geologicznego, 55, 201-250 [with English summary].

Olszewska B., 1999. Biostratygrafia neogenu zapadliska przedkarpackiego $\mathrm{w}$ świetle nowych danych mikropaleontologicznych [Biostratigraphy of Neogene in the Carpathian Foredeep in the light of new micropalaeontological data]. Prace Państwowego Instytutu Geologicznego, 168, 9-27 [with English summary].

Olszewska B. \& Malata E., 2006. Analiza paleośrodowiskowa i paleobatymetryczna zespołów mikroskamieniałości polskich Karpat zewnętrznych [Palaeoenvironmental and paleobathymetric analysis of microfossils assemblages of the Polish Outer Carpathians]. [in:] Oszczypko N., Uchman A. \& Malata E. (eds), Rozwój paleotektoniczny basenów Karpat zewnętrznych i pienińskiego pasa skatkowego, Instytut Nauk Geologicznych Uniwersytetu Jagiellońskiego, Kraków, 61-84.

Oszczypko N., 1998. The Western Carpathian Foredeep development of the foreland basin in front of the accretionary wedge and its burial history (Poland). Geologica Carpathica, 49, 415-431.

Oszczypko N., 2006. Late Jurassic-Miocene evolution of the Outer Carpathian fold-and-thrust belt and its foredeep basin (Western Carpathians, Poland). Geological Quarterly, 50, 1, 169-194.

Parsons J.D., Friedrichs C.T., Traykovski P.A., Mohrig D., Imran J., Syvitski J.P.M., Parker G., Puig P., Buttles J.L. \& García M.H., 2007. The mechanics of marine sediment gravity flows. [in:] Nittrouer Ch.A. et al. (eds), Continental Margin Sedimentation: From Sediment Transport to Sequence Stratigraphy, Special Publication of the IAS, 37, 276-337.

Picha F.J., Stráník Z. \& Krejčí O., 2006.Geology and Hydrocarbon Resources of the Outer Western Carpathians and their Foreland, Czech Republic. [in:] Golonka J. \& Picha F.J. (eds), The Carpathians and their foreland: Geology and hydrocarbon resources, American Association of $\mathrm{Pe}$ troleum Geologists Memoir, 84, 49-176.

Piotrowski J. \& Piotrowska K., 2004. Jednostki nieformalne mezozoiku i kenozoiku. [in:] Mardal T. (red.), Słownik jednostek litostratygraficznych Polski. T. 4, Państwowy Instytut Geologiczny - Państwowy Instytut Badawczy, Warszawa, 1-310.
Piper D.J.W., Cochonat P. \& Marrison M.L., 1999. The sequence of episodics around the epicentre of the 1929 grand Banks earthquake: initiation of debris flows and turbidity current inferred from sidescan sonar. Sedimentology, 46, 79-97.

Poprawa P., Malata T. \& Oszczypko N., 2002. Ewolucja tektoniczna basenów sedymentacyjnych polskiej części Karpat zewnętrznych w świetle analizy subsydencji. Przegląd Geologiczny, 50, 1092-1108.

Postma G., 1986. Classification of sediment gravity-flow deposits based on flow conditions during sedimentation. Geology, 14, 291-294.

Rajchel J., 1990. Litostratygrafia osadów górnego paleocenu i eocenu jednostki skolskiej. Zeszyty Naukowe Akademii Górniczo-Hutniczej im. Stanisława Staszica, 1369, Geologia, 48, Wyd. AGH, Kraków, 1-112.

Scheibnerova V., 1971. Implications of deep sea drilling in the Atlantic for studies in Australia and New Zealand - Some new views on Cretaceous and Cenozoic palaeogeography and biostratigraphy. Search, 2, 7, 251-254.

Severin K.P., 1983. Test morphology of benthic foraminifera as a discrimination of biofacies. Marine Micropaleonto$\log y, 8,65-76$

Smoleńska A. \& Dudziak J., 1989. Wiek margli podcergowskich na podstawie nannoplanktonu wapiennego. Geologia. Kwartalnik Akademii Górniczo-Hutniczej im. Stanisława Staszica w Krakowie, 15, 3, 29-40.

Szczechura J. \& Pożaryska K., 1974. Foraminiferida from the Paleocene of Polish Carpathians (Babica Clays). $\mathrm{Pa}$ laeontologica Polonica, 31, 1-142.

Szydło A., 2011. Agglutinated foraminifers from mass transport deposits: examples from the Northern Outer Carpathians. [in:] Kaminski M.A. \& Filipescu S. (eds), Proceedings of the Eighth International Workshop on Agglutinated Foraminifera, Grzybowski Foundation Special Publication, 16, 317-330.

Szymakowska F., 1976. Olisthostromes in the Krosno beds (Polish Middle Carpathians). Rocznik Polskiego Towarzystwa Geologicznego, 46, 39-54.

Ślączka A. \& Kamiński M. A., 1998. A guidebook to excursions in the Polish Flysch Carpathians. Grzybowski Foundation Special Publication, 6, 1-173.

Ślączka A., Oszczypko N., Malata E. \& Cieszkowski M., 1999. An early history of the Outer Carpathian basin. Geologica Carpathica, Special Issue, 50, 170-172.

Ślączka A., Kruglov S., Golonka J., Oszczypko N. \& Popadyuk I., 2006. Geology and Hydrocarbon Resources of the Outer Carpathians, Poland, Slovakia, and Ukraine: General Geology. [in:] Golonka J. \& Picha F.J. (eds), The Carpathians and their foreland: Geology and hydrocarbon resources, AAPG Memoir, 84, 221-258.

Wójcik A., Jankowski L., Kopciowski R., Malata T., Marciniec P. \& Nescieruk P., 1995. Opracowanie formalnych jednostek litostratygraficznych Karpat zewnętrznych izapadliska przedkarpackiego dla celów Szczegółowej mapy geologicznej Polski. Archiwum CAG, PIG, Warszawa [unpublished]. 